\title{
Subscriptions
}

APT Volume 8, 2002 (six issues) (note: full airmail £18/US\$29 extra).

Print (plus FREE on-line)

Members of the Non-members Institutions
Royal College

Royal College of Psychiatrists

Europe (\&UK)

$£ 42$

$£ 90$

$£ 102$

USA

$\$ 75$

Elsewhere

$\$ 156$

$\$ 174$

$£ 98$

$£ 109$

On-line (only)

\section{Members of the} Royal College of Psychiatrists

Worldwide $£ 30 / \$ 48$

Non-members Institutions

Payment may be made by cheque/money order, by Access/Master Card/ Visa/American Express, or by UNESCO coupons. EC subscribers: please supply your Member State Code and Value Added Tax (VAT) number.

Payment should be made to the Maney Publishing, Hudson Road, Leeds LS9 7DL, UK (Telephone: +44 (0)113 249 7481; facsimile: +44 (0)113 248 6983; e-mail: subscriptions@maney.co.uk). For subscriptions in North America, please contact Maney Publishing North America, 44 Brattle Street, 4th Floor, Cambridge, MA 02138, USA (Telephone: 8662975154 (toll free); facsimile: 617354 6875; e-mail: maney@maneyusa.com).

Continuing Professional Development (CPD): Those wishing to register for CPD should contact the CPD Unit of the Royal College of Psychiatrists (Telephone: +44 (0) 2072352351 ext. 112 or 108). There is no charge for participation in the CPD scheme for Members, Fellows and Affiliates of the Royal College of Psychiatrists.

Correspondence: Correspondence submitted for publication should be sent to Professor A. Sims, Royal College of Psychiatrists, 17 Belgrave Square, London SW1X 8PG.

Printed by: Henry Ling Ltd, 23 High East Street, Dorchester, Dorset DT1 1HD.

(c) The Royal College of Psychiatrists 2002. Published by the Royal College of Psychiatrists, a registered charity (no. 228636), 17 Belgrave Square, London SW1X 8PG. Unless so stated, material in Advances in Psychiatric Treatment does not necessarily reflect the views of the Editor or the Royal College of Psychiatrists. The publishers are not responsible for any errors of omission or fact.

The College crest is a registered trade mark of the Royal College of Psychiatrists.

ISSN $1355-5146$

Full text of $A P T$ is available on-line at http://apt.rcpsych.org/ 